\title{
False Fear from Marginalized Groups (Homeless, Orphans, Migrants) to Our Society - No Carriers of Dangerous Microorganisms
}

R. Kovac (Robert Kovac)', V. Krcmery (Vladimir Krcmery)5), M. Olah (Michael Olah)2, M. Smidova (Maria Smidova)4), G. Mikolasova (Gertruda Mikolasova)4, K. Prochazkova (Katarina Prochazkova)4, J. Polonova (Jaroslava Polonova)4, I. Kmit (Igor Kmit)4 ${ }^{4}$, P. Slavikova (Petra Slavikova) ${ }^{4}$, M. Jackulikova (Maria Jackulikova) ${ }^{6}$, M. Palenikova (Milica Palenikova) ${ }^{6}$, A. Topolska (Alexandra Topolska)5, S. Subramanian (Selvaraj Subramanian), L. Cintulova (Ludwiga Cintulova), J. Dacok (Jan Dacok)4, P. Stankova (Petra Stankova)4 , A. Shahum (Andrea Shahum) $^{3}$

${ }^{1}$ Shelter for Homeless Mea Culpa, St. Elizabeth University Homeless

\section{Original Article} Programe (SEUHP), Vrakuna, Bratislava, SK

${ }^{2}$ Shelter for Homeless Resoty, (SEUHP) Podunajske Biskupice, SK

${ }^{3}$ Orphanage House of Family, Phnom Penh, Kingdom of Cambodia, KH

${ }^{4}$ Daily Stationary for Homeless, (SEUHP), St. Elizabeth, Old Town, SK

${ }^{5}$ Refugee and Migrant Program, Homeless Program St. Elizabeth University Bratislava, (SEUHP) Slovakia and Kingdom of Cambodia, SK, KH

${ }^{6}$ Hospital Alexandria, GR

\section{E-mail address:}

tropicteam@gmail.com

\section{Reprint address:}

Igor Kmit

St. Elisabeth University of Health and Social Sciences

Nam. 1. Maja 1

81000 Bratislava

SK

Source: Clinical Social Work and Health Intervention

Pages: $54-57$

Volume: 9

Issue: 2

\section{Reviewers:}

Daniel J. West, Jr.

University of Scranton, Department of Health Administration and Human Resources, USA

Roberto Cauda

University Catholica Clinica, Gemeli, Rome, IT 


\section{Key words:}

Migrants. Orphans. Homeless.

\section{Publisher:}

International Society of Applied Preventive Medicine i-gap

CSWHI 2018; 9(2): 54 - 57; DOI 10.22359/cswhi_9_2_08 @ 2018 Clinical Social Work and Health Intervention

\section{Abstract:}

Summary: Purpose of this study was to determine if marginalized groups e.g. homeless, orphans, and/or migrants are a threat for our public health concerning communicable diseases.

Patients and Methods: 153 marginalized individuals, orphans, homeless, migrants were screened for pathogenic organisms.

Results: Only $1-3$ strains of MRSA per group have been observed. Majority of isolates were not pathogens. No single case of TB, HIV, HCV among migrants/homeless was observed.

Conclusion: Marginalized do not represent a threat for public health.

\section{Introduction}

There is an ongoing discussion about the danger of migrants, and homeless for local public health, however, studies on this issue are missing. The study on homeless (Italy, Slovakia) did not show higher proportion of TB among homeless, as was observed in the USA $(1,2)$. The aim of this research was to determine within a point prevalence study if marginalized clients of
Social Work are reservoirs or colonized by pathogenic bacteria.

\section{Patients and Methods}

Within a point prevalence study in $1^{\text {st }}$ week of January 2018, we cultured oropharynx of 153 marginalized clients: 50 homeless; 52 orphans; 51 migrants from Syria/Iraq and investigating for pathogenic

Table 1: Pathogens among isolates in marginalized.

\begin{tabular}{|l|c|c|c|c|c|c|}
\hline All & Homeless & Orphans & Migrants & P1 & P2 & P3 \\
\hline Total 153 & 50 & 51 & 52 & & & \\
\hline $\begin{array}{l}\text { S. aureus, } \\
\text { S. pyogenes }\end{array}$ & $5(10 \%)$ & $13(26 \%)$ & $3(6 \%)$ & NS & 0,01 & NS \\
\hline MRSA & $1(2 \%)$ & $4(8 \%)$ & $1(2 \%)$ & NS & 0,01 & NS \\
\hline Enterobacteriacae & $4(8 \%)$ & $7(14 \%)$ & $7(14 \%)$ & NS & NS & NS \\
\hline $\begin{array}{l}\text { Non-aeruginosa Ps. } \\
\text { (waterborne) }\end{array}$ & $2(4 \%)$ & $2(4 \%)$ & $5(10 \%)$ & NS & NS & 0,04 \\
\hline Candida spp. NA. Candida & $13(26 \%)$ & $13(26 \%)$ & $26(50 \%)$ & NS & NS & 0,01 \\
\hline HIV / AIDS & 0 & 0 & 0 & NS & NS & NS \\
\hline Tuberculosis & 0 & 0 & 0 & NS & NS & NS \\
\hline
\end{tabular}


bacteria. Statistical package EPI Info 2010 version of CDC was used.

\section{Results and Discussion}

Table 1 shows that an overall proportion of pathogens among all 3 groups of clients was minimal (2-8\%) and was higher significantly in orphans comparing to homeless. The majority of isolates were non-pathogenic bacteria and fungi $(2,3)$.

\section{Homeless and Migrants are not dangerous for host population}

Several studies have been accusing homeless as a threat to public health, especially as reservoirs of blood borne infections related to substance misuse such as heroin recipients or alcoholics. However, the majority of substance misusers belongs to the upper class due to large expenses related to drug use, therefore homeless among this group are less and less common. (3) Apart from HIV, hepatitis B, and hepatitis $\mathrm{C}$ in substance misusers, so rare currently among the homeless in Slovakia, tuberculosis was accused to be a driver as a public health threat. Again, in NYC and San Francisco, where TB is pandemic, most of EC homeless subpopulation is not sheltered but dispersed in parks, churches, in climatic mild cities such as Rome, Palermo, Athens, Marseille, Malaga, Barcelona, is low. Within a study with sheltered homeless in Bratislava 10 years ago, the major ID threat among homeless was not TB (0 prevalence) but concerned flu, easily preventable with simple vaccination. (4)

\section{Conclusion}

As seen in the results from our study, homeless and orphans as well as refugees and migrants are not a threat concerning communicable or non-communicable diseases for the public health of our host population. The prevalence of TB in Balkan countries where refugees and homeless are transiting is in most countries (Macedonia, Serbia, Albania, Romania, Bulgaria) is much higher than among migrants from Iraq and Syria. Also, the prevalence of HIV, HBV, and HCV among refugees from Middle East is much lower than of/in the host population of Ukraine, Russia and Balkan countries. Colonization of migrants, and travelers with multi-resistant bacterial pathogens such as MRSA is much lower than among the institutionalized (e.g. hospitalized) elderly population of host countries including Slovakia where a prevalence of MRSA, ESBL and KPC Enterobacteriaceae is low; higher than among migrants or travelers from the Middle East. Probably, different situations would be among those coming from North and Sub-Saharan Africa, where they use difficult transit through Central / East Europe.

\section{References}

1. MATEJOVA A (2013) International adoption under the Convention on the Protection of Children and Cooperation in International Acquisitions between the Slovak Republic and Italy, published in Minori Giustizia, no. 2/2013, FrancoAngeli, Milano, Italy, ISSN 1121-2845.

2. GREY E, HARDY M, SLADECKOVA V, ADAMCOVA J, BUCKO L, BLASKOVIC J, PAUEROVA K, DUDASOVA T, POLONOVA J, RABAROVA L, BENCA GJ (2017): Neurologic disorders in HIV-positive orphans: 10 years of follow up. Neuro Endocrinology Letters. 2013 Sept;34 (Suppl 1):36-7.

3. KOVAC R, MIKLOSKOVA M (2013) The impact of early childhood on the risk of homelessness. In: The International Journal of Prenatal and Perinatal psychology and Medicine. Peter G. Fedor-Freybergh. - Luxembourg: Maghira \& Maas Publications, 
ISSN 0943-5417. Year. 25, no. Suppl.1 (2013) p. 80-89.

4. OLAH, M., KOVAC, R., PROCHAZKOVA, K., MIKOLASOVA, G (2017) ID among homeless, Clinical Social work, H7, 2017, s. 4-17
5. OLAH M (Ed.) (2016) Alternative child custody "Cochem's Model". Nadlac. Editura Ivan Krasko, $1^{\text {st }}$ ed. pp. 221. ISBN 9789731071060. 